1

2

3

4

5

10

11

12

13

14

15

16

17

18

19

20

21

22

23

24

25

26

27

28

29

30

31

32

33

34

35

36

37

38

39

40

41

42

43

44

45

46

47

48

49

50

51

52

53

54

55

56

57

58

59

60

\title{
Trends and Patterns in Sustainable Tourism Research: A 25-Year Bibliometric Analysis
}

\begin{abstract}
In the quarter of a century since the release of the 1987 Brundtland Report, sustainable tourism has emerged as the dominant paradigm in tourism development. However, the debate, discourse and criticism of this sub-field of tourism research continues. To address such concerns the purpose of this paper is to explore trends and patterns in sustainable tourism research over the past 25 years. A 25 year bibliometric analysis was conducted for the four highest ranked journals in the tourism field. Results indicate that the growth in sustainable tourism research has been remarkable, with 492 papers published in these four journals and almost half of these in the last two years of the analysis. The largest proportion of papers published on sustainable tourism was case studies, empirical studies and critical reviews. This study found that while the theoretical and methodological approaches appear to have matured over time, the subjects and themes in sustainable tourism research, with some exceptions, have remained constant. However, the field is clearly maturing with a move away from definitional and conceptual papers to papers focused on testing and applying theory through empirical research.
\end{abstract}

Keywords: Sustainable tourism, research, content analysis, bibliometric 


\section{Introduction}

The notion of 'sustainable tourism' has, arguably, emerged to have one of the most noteworthy impacts on the field of tourism studies and scholarship (Bramwell \& Lane, 2011). Sustainable tourism evolved by drawing on the ideology of sustainable development that was popularised following the publication of the World Commission on Environment and Development's (WCED) Our Common Future in 1987. Widely referred to as the Brundtland report, its release sought multilateral support for enhancing awareness, cooperation and a more balanced approach to development (Dowling, 1993) "that meets the needs of the present without compromising the ability of future generations to meet their own needs" (WCED, 1987, p.43). This soon resonated in a tourism context, where 'sustainable tourism' began to appear in the vernacular of governments, tourism related industries, and tourism researchers to generally represent a more balanced approach to redressing the cumulative negative impacts of tourism activity that had manifest over the previous decades (Bramwell \& Lane, 2012; Saarien, 2006).

Sustainable tourism developed alongside, but separate to, its parent paradigm of sustainable development. As sustainable tourism gained traction in the literature, some have vehemently opposed the 'tourism-ification' (Hunter, 1995) of the concept, claiming that it ignores the broader tenets of sustainable development, or the conceptualisation of sustainable tourism as simply synonymous with eco or environmentally responsible tourism (Lu \& Nepal, 2009; Weaver, 2014). Further, numerous authors have criticized the scholarship of sustainable tourism research, with some commenting on the lack of progress in this subfield of tourism research (Bramwell \& Lane, 2005; Loulanski \& Loulanski, 2011), the ongoing and circular definitional debates (Gössling, Hall \& Weaver, 2009), the unresolved and inherent contradiction in the phrase 'sustainable tourism' (Torres-Delgado \& Palomeque, 2012) and the fact that the concept has still, to a large extent, not been adopted in practice 25 years postBrundtland (Lane, 2009; Holden, 2009). While sustainable tourism has been widely embraced by the academic and scientific community, these debates, discourses and criticisms have been a consistent feature of the literature.

It has been estimated that there are in excess of 5,000 published works on sustainable tourism (Buckley, 2012), a figure that, if judged by quantity, confirms that sustainable tourism has been a highly influential focus of tourism research. Given both the sheer volume of sustainable tourism scholarship, coupled with the ongoing and unresolved debates and criticism about the validity and contribution of the sustainable tourism research paradigm, a comprehensive and systematic analysis and review of published research on sustainable tourism is long overdue. Such a study is timely as 2012 marked the 25 year milestone of the release of the Brundtland report. 
State-of-the-art reviews are a common feature of academic work and, reflecting the maturation of tourism as an area of study, such articles are increasingly common in the field's leading journals. Indeed, it is recognised that systematic quantitative analyses of a body of literature in a particular field of study provides the means to definitively identify knowledge outcomes and paradigm shifts (Xiao \& Smith, 2006a, 2007). For instance, Xiao and Smith (2006a) undertook a content analysis of the subject index of Annals of Tourism Research (ATR) (1973-2003), identifying major subject areas and discussing patterns in the growth of tourism research as published in a single journal. Similar studies have been undertaken by Kim (1998), who examined the subject categories in ATR and Journal of Travel Research (JTR), while Swain, Brent, and Long (1998) also reported on key themes across time and by geographic region in ATR. Other reviews in a tourism context have included analysis of authorship (Sheldon, 1991), citations (Xiao \& Smith, 2006b), perceptions of journal quality by authors (McKercher, Law \& Lamb 2006; Pechlaner, Zehrer, Matzler \& Abfalter 2004; Sheldon 1990), methodologies (Reid \& Andereck 1989; Riley \& Love 2000; Xiao \& Smith 2006c), disciplines (Darbellay \& Stock 2012; Echtner \& Jamal 1997; Leiper, 1981, 2000; Tribe, 1997, 2000), the impact of tourism scholarship (Xiao \& Smith 2008), doctoral level research (Botterill, Haven \& Gale 2002; Hall 1991; Huang, 2011; Jafari \& Aaser 1988; Meyer-Arendt \& Justice 2002; Weiler, Moyle \& McLennan 2012) and changes in subject areas over a defined time period (Swain et al., 1998; Xiao \& Smith 2006a).

Despite the importance and proliferation of sustainable tourism there have been few rigorous bibliometric analyses of sustainable tourism research. Bibliometric analysis is the systematic quantitative analysis of academic literature to measure scientific progress (Ramos-Rodriguez \& RuizNavarro, 2004; Van Raan, 2004), commonly undertaken using techniques such as citation analysis, co-citation analysis and content analysis (Shilbury, 2011; Ramos-Rodriguez \& Ruiz-Navarro, 2004). Early on, Butler (1999) provided a summary of the work that had been conducted in the realm of sustainable tourism over the decade following the Brundtland report. Later, Lu and Nepal (2009) undertook a content analysis of all articles published in the Journal of Sustainable Tourism (JOST) from 1993 to 2007 . As JOST is the only journal in the field dedicated to sustainable tourism, the authors used the analysis to draw conclusions about the growth and trends in sustainable tourism research more generally. More recently, Buckley (2012) undertook a review of the scope, focus and outcomes of academic research in sustainable tourism. While the methodological approach employed was not explicit, Buckley (2012) focused on sustainable tourism research that has been conducted on social and environmental impacts, responses, and indicators, based on the categories of population, peace, prosperity, pollution and protection.

A detailed and longitudinal bibliometric-based analysis of sustainable tourism research fills a key gap in rigorously, systematically and objectively examining how sustainable tourism research has changed 
over time. Given this context, and based on approaches applied to other tourism bibliometric-based reviews (Lu \& Nepal 2009; Weiler et al., 2012; Xiao \& Smith 2006a), this paper undertakes a longitudinal analysis of sustainable tourism research as published in the four leading journals in the tourism field: Annals of Tourism Research (ATR), Journal of Sustainable Tourism (JOST), Journal of Travel Research (JTR) and Tourism Management (TM) (McKercher, Law \& Lam 2006; Lu \& Nepal, 2009; Ryan 2005) over the 25 year period since the release of the Brundtland report (1987-2012). The aim of the study is to identify trends and patterns in sustainable tourism research and scholarship.

The study's ambitious scope and rigorous methods - a bibliometric analysis of 492 papers - make the findings important and timely, and provide indicators of, and insights as to, how this subfield of tourism research has developed over time. This is achieved through meeting the following objectives: 1) to identify the theoretical and methodological approaches used in sustainable tourism research;2) to classify the major subjects and contextual themes in sustainable tourism research;3) to identify the perspectives/approaches applied to the study of sustainable tourism; and, 4) to identify geographic/locational patterns in sustainable tourism research. The correlations between dimensions within and across each of these objectives are examined, as well as the correlation to journals. From the study's findings, conclusions are drawn about trends and patterns in a quarter of a century of sustainable tourism research that has occurred since Brundtland, which in turn provides insights into the opportunities and directions for the coming decades of research in this particular subfield of tourism studies.

\section{Sustainable Tourism Research}

Notwithstanding Lu and Nepal's (2009) analysis of 15 years of JOST publications, there has been no comprehensive, multi-journal bibliometric analysis of sustainable tourism research. However, there have been a number of literature reviews and commentary pieces on the state of sustainable tourism research (Bramwell \& Lane, 1993, 2008, 2012; Gössling, Hall \& Weaver, 2008; Hardy, Beeton \& Pearson, 2002; Ko, 2001; Scott, 2011; Torres-Delgado \& Palomegue, 2012). While it is not the objective of this particular paper to again traverse this well documented space, it is fitting to summarise the macro themes and trends these authors have highlighted to provide context to the findings and discussions of the current study.

Much of the early work focused on defining sustainable tourism, proposing and revising concepts and debating the theoretical, practical and philosophical nuances of the topic. Indeed, some authors have been highly critical of the academy's 'navel gazing' and for not advancing the concept beyond the theoretical to explore, among other things, how the concept can be legitimately applied in practice (Sharpley, 2000). Yet the literature has clearly shifted in some respects; published research has moved from the conceptual to empirical, with researchers moving to test earlier theoretical propositions ( $\mathrm{Lu}$ 
\& Nepal, 2009). The maturity of this subfield is also evident with research generally moving beyond myopic views of environmental issues to addressing sustainable tourism in a more holistic fashion that recognises the socio-cultural, economic and political aspects of the concept (Bramwell, 2007), which is more in keeping with the tenets of sustainable development.

A strong theme within sustainable tourism research, particularly through the $1990 \mathrm{~s}$, has been research focused on eco, nature-based and alternative forms of tourism. Recognising that it is highly contestable whether such tourism genres are synonymous with sustainable tourism, tourism researchers have focused extensively on this particular area of sustainable tourism research. Indeed, Lu and Nepal (2009) found that 58\% of the papers published in JOST between 1993 and 1997 focused on eco or nature-based tourism. Much of the literature during this period advocated small-scale tourism, thus creating synergies with eco and nature based tourism. Some saw the impacts of mass tourism as so abhorrent that all 'small-scale' tourism activities were also (again whether rightly or wrongly) placed under the umbrella of sustainable tourism and seen to be largely synonymous with the concept (Collins, 1999; Singh \& Singh, 1999).

By the turn of the century, perhaps recognising that sustainable tourism had diverged too far from its parent paradigm, more holistic standpoints on sustainable tourism were pervading the research, shifting the focus back to the triple bottom line (economic, social and environmental). By the end of the first decade of the $21^{\text {st }}$ century there was also recognition of the importance of social responsibility and ethics within the sustainable tourism paradigm, concomitantly research into the genre of pro-poor tourism became more prevalent (Berke, 2002; Bramwell, 2007). Notably, sustainable tourism was no longer focused on developing a specific type of tourism product or reducing environmental impacts, rather it had advanced to become an overarching paradigm or goal that could be applied in a range of contexts (Lu \& Nepal, 2009). In recognizing that sustainable tourism was about more than eco and niche tourism, the pendulum swung back to critically exploring mass tourism under a sustainable tourism perspective (Weaver, 2012).

More recently, climate change has emerged as a major issue for the global political and economic agenda, as well as for the tourism industry (Bramwell \& Lane, 2012; Scott \& Becken, 2010; Scott, 2011), and it has led to a considerable increase in climate related tourism research (Gössling \& Hall, 2006; Gössling \& Peeters, 2007). Some see climate change as pushing sustainable tourism back onto the global political agenda (Scott, 2011; Weaver, 2011); certainly it has renewed the focus on the environmental aspects of tourism development. For instance, Bramwell and Lane (2008) note that the recent emphasis on the impact of tourism on the environment, which has been generated by the climate change debate, is similar to the early focus of research on sustainable tourism. 
In the two published reviews of sustainable tourism research, Buckley (2012) and Lu and Nepal (2009) both suggest there are several subject areas within sustainable tourism research that have remained consistently popular over their periods of analysis. In their review of JOST articles, Lu and Nepal identify five subject areas: tourism impact; sustainability assessment; development; visitor behaviour and attitude; and planning. While sustainability assessment is explicitly associated with sustainable tourism, the other four themes are aligned with the topic areas most researched in general tourism research (Xiao \& Smith, 2006a). They draw the conclusion that sustainable tourism research has generally mirrored trends in tourism research generally. In contrast, Buckley (2012) concludes that the four most popular subject areas in sustainable tourism are ecotourism, responsible tourism, community tourism and conservation tourism. These are, of course, tourism study contexts rather than subject areas. Contributing to the body of work on state-of-the-art reviews (Butler, 1998; Buckley, 2012) and extending the only bibliometric-based analysis of the sustainable tourism literature ( $\mathrm{Lu} \&$ Nepal 2009), the present study builds on these approaches to undertake a comprehensive and longitudinal review and analysis of sustainable tourism research.

\section{Study Methods}

As noted earlier, bibliometric studies are characterised by their use of statistics to analyse academic literature. Key bibliometric indicators include the number of articles, the number of authors, authors' productivity, and the productivity of countries or journals, while there are also standard bibliometric laws, including Price's, Lotka's and Bradford's laws (Guilera, Barrios \& Gómez-Benito, 2013; Barrios, Borrego, Vilaginés, Ollé \& Somoza, 2008). Price's Law argues that scientific production occurs exponentially (Guilera et al., 2013), while Lotka's law considers the relationship between the number of authors and the number of articles, suggesting a small number of authors publish a large number of articles (Pao, 1985). Bradford's law describes how the articles in a field are spread across journals, postulating that the majority of articles in a field are centred in a certain number of core journals, with decreasing information density in the more peripheral journals (Barrios et al., 2008). Importantly, bibliometric studies provide indicators of research production in a field over time and allow scholars to study science as a knowledge creation system (Van Raan, 2005).

Bibliometric studies have previously been applied in a tourism context (Benckendorff \& Zehrer, 2013; Weiler et al., 2012), and there are many commonalities in the methodological approaches that have been used. Studies have applied content analysis techniques to scrutinise the subject indices of the journal as a means of identifying key subject areas and patterns (Swain et al., 1998; Xiao \& Smith, 2006b), and several studies have assessed titles, abstracts and keywords to cumulatively identify subject categories or themes (Lu \& Nepal, 2009; Kim, 1998; Xiao \& Smith, 2006a; Weiler et al., 2012), while others have sampled entire articles to identify subject themes (Ballantyne, Packer \& Axelsen, 2009). Some studies have conducted analyses of single journals (Lu \& Nepal, 2009; Swain 
et al., 1998; Xiao \& Smith, 2006a), while others have assessed multiple publication sources (Ballantyne et al., 2009; Kim, 1998; Sheldon, 1991; Xiao \& Smith 2006b).

In the present study, the four highest-ranked journals in the field of tourism were selected for analysis. Assessments have consistently ranked ATR, JOST, TM and JTR, or a combination of these, as the leading journals in the field of tourism research (Ballantyne et al., 2009; McKercher, 2005; McKercher, Law \& Lamb, 2006; Pechlaner, Zehrer, Matzler \& Abfalter, 2004; Ryan, 2005), with these journals having a 2012 impact factor of 3.683, 3.000, 2.571, and 1.899 respectively (Thomson Reuters, 2013). While acknowledging the subjectivity and dissidence associated with journal rankings, and not discounting the quality of other journals which periodically have been ranked highly in the field (Frechtling, 2004), for the purposes of identifying a clearly delineated sampling framework for this study, the selection of the current four leading journals was deemed appropriate and is consistent with other bibliometric studies conducted in tourism. It is acknowledged that research on sustainable tourism is published in many other journals within and outside tourism related journals (Buckley, 2012). However, the four journals selected can be argued to sufficiently capture the scholarly breadth and depth of sustainable tourism research so as to address the study's aim and objectives.

The sampling framework was based on a 25 year period (1987 to 2012 inclusive). As noted previously, this selection was made to coincide with the 25 year milestone of the Brundtland report and the resulting permeation of the sustainable tourism concept into research and scholarship. It is of course acknowledged that sustainability has a history that predates Brundtland. To create the dataset for analysis, the four journals were searched for published research papers that focused on 'sustainable tourism' or 'sustainable development' over the 25 year period of analysis. To ensure that any relevant paper was not omitted the search terms included variations such as 'sustainability', 'sustainable' and 'sustain'. Only full research articles were included in the analysis, thereby excluding editorials, research or practitioner notes, and conference reports (Xiao \& Smith, 2006a). Papers were entered into an Excel spreadsheet for further analysis. Key bibliometric details recorded in the Excel database included the journal title, publication date, author details (name/s and location/s), article title, keywords, and abstract.

Once collected, the dataset was refined through a careful review of each paper's abstract to determine whether the aims, objectives or outcomes of the paper were in fact focused on sustainable tourism or a derivative of this. It was found that approximately $5 \%$ of papers in the dataset were not focused on sustainability and these were discarded from the dataset before analysis. The refined and final dataset contained 492 papers focused on sustainable tourism. At this stage, analysis of the entire article was undertaken via manual open binary coding. This round of analysis focused on addressing: the 
theoretical and methodological approaches and constructs of the paper (i.e. developing or testing theory/model, a case study, a conceptual review) (Objective 1); the major subjects and contextual themes of the paper (i.e. ecotourism, rural tourism) (Objective 2); the perspective/approach of the paper (i.e. behavioural studies, policy studies) (Objective 3); and the geographic/locational patterns of the research (Objective 4).

Initially, bibliometric analysis for the current study considered Price's law, that is, whether growth had been exponential, with the Bradford and Lotka laws being deemed beyond the scope of the current research. Next, the binary coding of the different approaches, themes, perspectives and locations were analysed for significant differences using pair-wise correlations and chi-square tests in STATA v.12. Following Lu and Nepal (2009), the data were initially grouped into six 5-year periods. However, this restricted the analysis as the sample size was too small to undertake statistical tests comparing the time periods, particularly in the earlier years. As previous authors had used descriptive analyses only, they had not previously encountered this problem. Therefore, to enable the use of statistical tests, the groups were collapsed into the following time periods: 1988-1997 (65 articles), 1998-2007 (207 articles) and 2008-2012 (220 articles). The first two periods each span 10 years and while the third period covers only five years it has the largest sample of publications given the considerable growth in recent years.

\section{Trends and Patterns in Sustainable Tourism Research}

A total of 492 papers was collected and coded across the four journals over the 25 year time span (Figure 1). Over half of the papers (56\%) were published in the dedicated sustainable tourism outlet JOST, followed by TM (25\%), ATR (13\%) and JTR (6\%). Considering Price's Law, the sustainable tourism papers follow a second-order polynomial trend $\left(\mathrm{y}=0.0644 \mathrm{x}^{2}+0.3998 \mathrm{x} ; \mathrm{R}^{2}=0.8633\right)$, reflecting the slow growth prior to 1993. However, plotting the growth from 1993 onwards shows exponential growth in the number of papers published relating to sustainable tourism $\left(y=5.578 \mathrm{e}^{0.0858 x}\right.$; $\mathrm{R}^{2}=0.8855$ ), with rapid growth in the latter years; notably the increase of $51 \%$ between 2011 and 2012 (from 47 to 71 articles) (see Figure 1). The first publication appeared in 1989 in TM, with one each in ATR and TM in 1991. With the launch of JOST in 1993, a further nine papers were published across the journals. From here, as can be seen in Figure 1, the trajectory begins to increase considerably. Notably, there was no significant difference $(\mathrm{p}=0.300)$ in the growth of sustainable tourism research between the four journals over the three analysed time period groupings, indicating that the rapid growth was general and not the result of any one journal. Regardless, the slight softening in the publication rate between 2003 and 2009 was primarily associated with ATR and TM, with JOST and JTR publications continuing to grow during the period.

Insert Figure 1 Growth in sustainable tourism research in the four leading tourism journals, 1987-2012 


\section{Objective 1: Theoretical and methodological approaches in sustainable tourism research}

The leading journals in the field each have a strong emphasis on theoretical, conceptual, empirical and methodological development, with papers published in the journals generally judged on their capacity to contribute in one or more of these aspects. Therefore, each of the papers identified in the dataset were assessed for their primary theoretical or methodological approach (see Table 1 for codes and code descriptors used). The largest proportion of papers published on sustainable tourism over the period of analysis were case studies (35\%), followed by empirical studies (17\%) and critical reviews (16\%) (Table 1). There were significant differences in the theoretical and methodological approach of papers published in the four journals $(\mathrm{p}<0.001)$. In particular, the journals varied in terms of their focus on case studies $(\mathrm{p}<0.001)$ with TM and JOST being more likely to include case studies than ATR and JTR. In contrast, JTR and ATR were more likely to focus on theory (methodology) development $(\mathrm{p}<0.001)$ than JOST and TM. Considering changes over the past 25 years, case studies $(\mathrm{p}<0.002)$ and literature reviews $(\mathrm{p}<0.001)$ have significantly declined, while empirical studies have gradually increased $(\mathrm{p}<0.001)$.

Insert Table 1 Theoretical and methodological approaches in sustainable tourism research

\section{Objective 2: Subjects and contextual themes in sustainable tourism research}

The subject areas of sustainable tourism research were analysed, that is, the focus or contextual theme of each paper. As explained in the methods section, this was achieved through a coder reviewing the entire article, and together with the article keywords, coding the paper on the basis of its overall focus or theme (see Table 2 for the codes and descriptors used). The analysed articles predominantly focused on sustainable tourism practice as a general construct (19\%) (i.e. conceptually driven papers focused on processes, practices, theories or trends), sustainable tourism development (10\%) (i.e. developing tourism in a sustainable manner), nature-based tourism (7\%) (i.e. general and/or wildlife based experiences in natural settings), protected areas (7\%), small island destinations (7\%) and ecotourism (6\%). All four of the journals had a strong focus on the more generalist sustainable tourism practice and sustainable tourism development subject themes, with considerable variation in their inclusion of the more specific sustainability themes ( $p=0.044$ ) (Table 2). Notably, TM was found to have a significantly greater focus on nature-based tourism (14\% of all articles) than the other three journals $(\mathrm{p}=0.012)$, while JOST and ATR were significantly more likely to publish sustainability articles on heritage tourism than TM and JTR ( $\mathrm{p}=0.006$ ). Notably, JOST was significantly more likely to publish sustainability articles on climate change than TM, ATR and JTR ( $p=0.037)$.

The subject areas in sustainable tourism research have significantly changed over the 25 year period of analysis. For instance, there has been a significant decline $(p=0.001)$ in the proportion of articles 
that are focused on sustainable tourism development (down from $23 \%$ in $1988-1997$ to just $7 \%$ in 2008-2012). There has also been a significant $(\mathrm{p}=0.025)$ growth in protected areas research (up from $3 \% 1988-1997$ to $10 \%$ in 2008-2012). Several of the subject areas have appeared more recently in the journals, with climate change and event tourism for instance, only appearing in the articles since 1997. Subject areas such as event tourism $(\mathrm{p}=0.024)$ and sustainable tourists/behaviour $(\mathrm{p}=0.013)$ have had significant growth since 2008.

In assessing the correlation between subject of the research and the theoretical or methodological approach employed in the paper, it was found that the nature-based tourism theme was significantly positively correlated with case studies $(\mathrm{p}=0.007)$, while sustainable tourism practice was significantly positively correlated with critical reviews $(\mathrm{p}<0.001)$ and framework building $(\mathrm{p}=0.048)$. The climate change theme was significantly correlated with critical reviews $(\mathrm{p}=0.049)$, while accommodation was positively correlated with empirical studies $(\mathrm{p}=0.027)$ and research on tourists was positively correlated with empirical studies $(\mathrm{p}=0.001)$ and index/scale building $(\mathrm{p}<0.001)$.

Insert Table 2 Subjects and contextual themes in sustainable tourism research

\section{Objective 3: Perspectives/approaches to sustainable tourism research}

The perspective or approach underpinning the article was examined, again by the coder reviewing the entire article to determine the primary perspective/approach taken in the paper. This differs from the analysis of the subject/theme of the paper as, for instance, a paper may examine an ecotourism issue using behaviour change theory or a climate change problem from a policy studies perspective (see Table 3 for the coding descriptor used). The analysed articles drew on a variety of perspectives and approaches, notably planning (19\%), behavioural studies (12\%), perception studies $(11 \%)$, tourism research theories/methods $(10 \%)$, indicators and measurement tools $(9 \%)$, policy studies $(9 \%)$ and stakeholders $(9 \%)$.

There were some notable differences between the four journals in terms of the perspective/approach of the articles published over the period. Firstly, ATR was significantly more likely to publish articles that used a policy studies perspective, with JOST and JTR significantly less likely to publish policy studies $(\mathrm{p}=0.041)$. ATR and JOST were significantly more likely to publish tourism research theory/methods (i.e. definitional debates, methodologies, discussions on ontology, methodology, paradigms) than JTR and particularly TM $(\mathrm{p}=0.003)$.

In terms of changes over time, there was only significant growth in perception studies (up from 3\% in $1988-1997$ to $13 \%$ in 2008-2012) ( $\mathrm{p}=0.022$ ), with other perspectives/approaches remaining relatively stable as a proportion of all articles in the time periods. Considering the correlation between the 
articles' subject/theme (Table 2) and the perspective/approach applied in the paper (Table 3), it was found that studies underpinned by a planning perspective were positively correlated with the subject of sustainable tourism in developing countries $(\mathrm{p}=0.016)$ and sustainable tourism development generally $(\mathrm{p}=0.043)$. Papers on sustainable tourism practice were instead positively correlated with general tourism research approaches $(\mathrm{p}<0.001)$, perception studies $(\mathrm{p}=0.025)$ and indicators and measurement tools $(\mathrm{p}<0.001)$.

Behavioural studies, as the paper's underpinning perspective/approach, were significantly positively correlated with alternative tourism $(\mathrm{p}<0.001)$ nature-based tourism $(\mathrm{p}<0.001)$ and sustainable tourists/behaviour $(\mathrm{p}=0.002)$, whereas policy studies were positively correlated with research on coastal destinations $(p=0.004)$. Stakeholder perspectives were positively correlated with studies of cultural tourism $(p<0.001)$, impact studies positively correlated with event tourism $(p=0.027)$ and visitor management positively correlated with nature-based tourism $(p<0.001)$, outdoor recreation/sport tourism $(\mathrm{p}=0.004)$ and protected areas $(\mathrm{p}=0.016)$. Marketing was positively correlated with heritage tourism $(\mathrm{p}=0.001)$ and sustainable tourists/behaviour $(\mathrm{p}<0.001)$. Papers underpinned by climate change studies were positively correlated with transport $(\mathrm{p}=0.005)$.

Looking at the correlations between the research perspective/approach and the theoretical or methodological approach employed in the paper, behavioural studies were significantly positively correlated with empirical studies ( $\mathrm{p}=0.031$ ), economic studies were significantly positively correlated with methodology development $(\mathrm{p}=0.001)$, and stakeholder research was significantly positively correlated with concept development $(\mathrm{p}=0.025)$. In addition, perception studies were found to be positively correlated with empirical studies $(p=0.015)$ and planning was positively correlated with case studies $(\mathrm{p}=0.019)$. Tourism research theory and methods was significantly positively correlated with literature reviews $(\mathrm{p}=0.004)$, concept development $(\mathrm{p}=0.004)$ and philosophical development $(\mathrm{p}=0.027)$. Impact studies were positively correlated with index/scale building $(\mathrm{p}=0.002)$. Finally, visitor management was positively correlated with case studies $(\mathrm{p}=0.033)$.

Insert Table 3 Perspectives/approaches to sustainable tourism research

\section{Objective 4: Geographic/locational patterns in sustainable tourism research}

The geographical location of authors, both by region and individual country, was coded based on the lead author's institutional affiliation at the time of publication. The majority of the papers during the period were from authors in the United Kingdom (119 papers or 24\%), Australia (98 papers or 20\%), the USA (76 papers or 15\%), Canada (33 papers or 7\%), New Zealand (23 papers or 5\%), Spain (18 papers or $4 \%$ ) and the Netherlands (12 papers or $2 \%$ ). Authors from the top five countries together accounted for $71 \%$ of all the papers published over the period. 
Analysis was also performed on the research location, that is, the particular region or country where the study took place. Approximately $19 \%$ of the papers $(n=93)$ are general conceptual or theoretical discussions and do not make reference to a particular locale. Consistent with the location of the authors above, most studies were undertaken in the regions of North-West Europe (16\%), followed by Oceania (16\%), North America (11\%), South and Eastern Europe (11\%), Sub-Saharan Africa (6\%) and North-East Asia (5\%). Regions that were under researched included Southern and Central Asia, South-East Asia, North Africa and the Middle East, South America, Antarctica and the Arctic. There was a significant difference between the four journals and the region in which the study was undertaken $(\mathrm{p}<0.001)$, with ATR papers being more likely not to make reference to a particular location, JTR being more likely to include American focused case studies, and JOST and TM being more likely to publish studies focused on Oceania and North-West Europe. There was also a significant change over time with the earlier articles (i.e. those published between 1989-1997 and 1998-2007) being more likely to focus on no particular locale or North-West European case studies, while more recent articles (i.e. those published between 2008-2012) being more likely to focus on case study localities in the Americas and Oceania. At the country level, studies were focused in Australia (53), the UK (51), USA (36), Spain (19), Canada (19), New Zealand (15), China (13) and Turkey (10).

\section{Discussion}

By sheer quantity alone, the growth in sustainable tourism research over the past 25 years is noteworthy. From slow beginnings the trajectory is exponential; a $51 \%$ increase in the last two years of the analysis is remarkable and directly counters the claims by some that sustainable tourism research has peaked and is in decline (Scott, 2011; Sharpley, 2009; Weaver, 2011). This exponential growth was not due to an increase in output in this area of research by any one of the journals, with all four journals experiencing similar growth. The growth in sustainable tourism does reflect to some degree the exponential growth that has occurred in tourism research more generally (Weiler et al., 2012). Other explanations for the growth include the entrance of JOST in 1993, and journals (including JOST) increasing their number of published issues per year.

Returning to some of the criticisms of sustainable tourism research outlined in the introduction to this paper (Bramwell \& Lane, 2005; Holden, 2009; Lane, 2009; Loulanski \& Loulanski, 2011), the research findings indicate that there has been considerable progress in sustainable tourism research. The analysis undertaken here points to a clear maturation in the study of sustainable tourism from the early generalist papers that focused more broadly on definitional and conceptual debates, and the development of frameworks and models to explain the sustainability construct. Such papers were arguably crucial in embedding the sustainability paradigm within a tourism context. 
The criticism that sustainable tourism research is characterised by ongoing and circular definitional debates (Gössling, Hall \& Weaver, 2009) is less relevant in more recent years with a clear move away from definitional and conceptual papers to papers focused on testing and applying theory through empirical research. For instance, literature review papers on the topic have largely disappeared (15\% in the period 1988-1997 to $2 \%$ in 2008-2012) with a clear shift towards empirically driven research; in 1988-1997 only 3\% of analysed papers were coded as empirical but by 2008-2012 this had increased considerably to $25 \%$ of all papers. Consistent with this trend towards empirically based studies, case studies, which had been the dominant approach utilised in sustainable tourism research (35\% of all articles) have declined over time ( $43 \%$ in the period $1988-1997$ to $27 \%$ in the period 2008-2012). This finding updates that of Lu and Nepal (2009), who at the time of their analysis identified case studies as the most common method employed in the study of sustainable tourism. The current bibliometric analysis, also influenced by the broader scope of journals sampled, does show that the field is maturing in terms of the shift from case study to empirical research using sophisticated quantitative and qualitative analysis. This is congruent with Xiao and Smith's (2006a, p.503) assertion that, "the growth of knowledge around methodology and theoretical constructs is indicative of the efforts of a young field to achieve rigor and to be recognized as a 'serious' field of enquiry". Other reasons for this change may include researchers self-adjusting in response to the criticisms of sustainable tourism research and attempting to break out of the cyclical debates that were necessary while 'bedding down' the underpinning tenets of sustainable tourism as a subfield of tourism research. Alternatively, this may simply be a reflection of the times and the increasing sophistication of the study area where the more applied and basic case study approaches are no longer considered sufficiently 'academically rigorous' to warrant publication in the leading journals in the field.

When compared to the changes in the field from a theoretical and methodological perspective, the subjects and contextual themes of sustainable research have remained more stable, with certain themes remaining relatively constant across the 25 year period. Examples include nature based tourism (9\% in the period 1988-1997 and 7\% in the period 2008-2012) and ecotourism (5\% in both the periods of 1988-1997 and 2008-2012). Again returning to the criticisms of sustainable tourism research outlined in the introduction to this paper, the assertion that sustainable tourism is often seen as synonymous with ecotourism and nature based tourism (Lu \& Nepal, 2009; Weaver, 2014) is probably a correct one. The cumulative proportion of papers focused on nature-based, ecotourism and protected area tourism (20\%), shows this to be an important subject or context of sustainable tourism research over the 25 year period. As such, it is not surprising that inferences are made that sustainable tourism and ecotourism are synonymous, or in fact that sustainable tourism is disproportionately focused on the environmental aspects of tourism as compared to the broader triple bottom line 
expectations of sustainable development, where for instance social/cultural studies $(6 \%)$ have received comparatively far less attention in the literature.

Again indicative of the maturation of this sub-field of tourism research the proportion of papers focused on the more general constructs of sustainable tourism and sustainable tourism development have declined from $23 \%$ to $7 \%$ over the period of analysis. As the field moves away from the cyclical debates and discourse around the conceptual basis of sustainable tourism other areas of focus are moving to the fore. For instance, looking towards the emerging research themes in sustainable tourism, there have been modest increases in research focused on new thematic areas over the periods of analysis including climate change (0 in the period 1988-1997, 3\% in the period 1998-2007 and 5\% in 2008-2012) and events ( 0 in the period 1988-1997, 2\% in the period 1998-2007 and 5\% in 20082012). It is likely that there will be continued increases in the numbers of papers focused on climate change over the coming decades coupled with related topics such as behavioural change, risk, resilience, resource scarcity and transportation. This concurs with the findings of policy based studies of sustainable tourism which have found that Australian tourism strategic planning documents have evolved from a focus on nature-based, social and triple-bottom-line concepts towards a focus on climate change, responsibility, resilience, adaption and transformation (Moyle et al., 2013).

Separate to the subject and contextual themes within which sustainable tourism research is set, an analysis of the perspective/approach of the paper provides valuable indications of trends and patterns within this sub-field of research. Planning/management/strategy have been the dominant approaches to the study of sustainable tourism to date and, while there has been an overall decline, the approach has remained relatively constant over the periods of analysis (25\% in the period $1988-1997,20 \%$ in the period 1998-2007 and 17\% in 2008-2012). This focus on the management aspects of sustainable tourism aligns with tourism research trends more generally where from the 1980s onwards management was a key focus of research (Xiao \& Smith, 2006a); a trend that could be attributable to the positioning, in many parts of the world, of university level tourism studies (and thus researchers) within business and management faculties. Further, the prevalence of supply side research is consistent with the inherent assumptions that governments have a role to play in facilitating and/or driving sustainable development within destinations.

Comparatively less attention has been given to the demand side aspects of sustainable tourism. Behavioural studies (12\% in the period 1988-1997, $11 \%$ in the period 1998-2007 and 14\% in 20082012 ) and perception studies (3\% in the period 1988-1997, 10\% in the period $1998-2007$ and $13 \%$ in 2008-2012) have been a constant feature of sustainable tourism research specifically and are congruent (although less markedly) with the broader focus in tourism research on consumer behaviour and psychology (Xiao \& Smith, 2006a) While not momentous increases, research focused on 
indicators and measurement tools has grown (5\% in the period 1988-1997 and 10\% respectively in the periods 1998-2007 and 2008-2012), reflecting again the growing maturity of the field in terms of the move away from case studies to empirically driven theory development (Table 1) as well as the increasing use of software that facilitates more complicated statistical analysis.

Several of the correlations uncovered in the analysis are expected, for example, between visitor management, protected areas and the use of case studies; and between marketing and tourist behaviour. In addition, the correlation between economic studies and methodology development is unsurprising with many of the economic studies using econometric techniques. Some of the nuances in terms of correlations between variables may reflect disciplinary traditions in fields such as planning, where researchers frequently engage in case study approaches and focus on issues in developing countries.

Most sustainable tourism research was undertaken in the regions of North-West Europe, Oceania and North America, with little research on Central and Southern Asia, North Africa and the Middle East, South and Central America, and the Arctic and Antarctica. While there has been some growth in the number of studies conducted in these latter regions, as a proportion of all studies, these remain underrepresented. However, more recent articles have shown a trend towards focusing on the Americas and Oceania, with a shift away from European based studies. Again, this is a trend that could be indicative of the growth of tourism degree programs outside of Europe, and the movement of academics to institutions in Asia, Australia and New Zealand. For instance, authors from the UK, Australia, USA, Canada and NZ together account for $71 \%$ of all papers published over the period, a finding consistent with other authorship studies in tourism research (Lu \& Nepal, 2009; Weiler et al., 2012).

The large number of studies focused on Australia and the UK correlates with the authors' region of residence. There are clear correlations between the location of the author/s and the geographical focus of the published research. This finding is not unexpected given researchers personal networks and contacts are likely to be more limited to those in their 'home' country and research funding (albeit declining in many parts of the world) is often tied to national research priorities or local contextual issues. However, changes to the status quo are evident with the number of country level studies growing over the period in countries such as China, where there were no studies prior to 1997, but 13 between 1998 and 2012.

Contrasting the current findings with previous reviews of the sustainable tourism literature, these findings concur to some extent with Buckley's (2012) assertions that the research contexts noteworthy for sustainable tourism were identified several decades ago and have changed little. Yet the objectiveness of the bibliometric approach has provided a more rigorous assessment of the state of the 
field. For instance, while Buckley similarly notes the growth of climate change, his assessment omits the emergence, for example, of events within the sustainable tourism literature. Similarly, on the one hand the current findings concur with Lu and Nepal's assessment of the published articles in JOST with regards to the continued importance of topics such as ecotourism and nature based tourism. However, the wider scope of the present research has highlighted that in fact early sustainable tourism research was largely concerned with generalist definitional and conceptual papers, with a later wave of papers focused on empirically driven theory testing and building. The present study also reveals that, unlike Lu and Nepal's (2009) findings, case study research is no longer the dominant approach of sustainable tourism research, replaced by empirical studies underpinned by quantitative and qualitative analyses.

\section{Conclusion}

Given the volume of sustainable tourism studies as a sub-field of tourism research, this paper sought to explore the trends and patterns evident in sustainable tourism research since the release of the Brundtland report in 1987, a milestone event which is generally acknowledged as mainstreaming sustainable development and similarly provided the impetus for the concept to be adapted into a tourism context. Even 25 years on from Brundtland and despite the prevalence of the concept, debate and critique continues, with authors noting a raft of shortcomings (Bramwell \& Lane, 2013; Buckley, 2012; Gössling, Hall, Ekstrom, Engeset \& Aall, 2012). It was against this background that a bibliometric analysis of the four leading tourism journals was undertaken to quantify if there have in fact been discernable patterns and shifts in theoretical/methodological approaches, the subjects/themes, the perspectives/approaches employed, and the geographic focus of sustainable tourism over the past 25 years.

The results indicate that there has been evolution in the theoretical and methodological approaches, as well as the subjects and themes employed in the subfield of sustainable tourism research. Reflecting the maturation of this sub-field of research there has been a clear move away from definitional and conceptual reviews to empirically driven theory testing and building. In terms of the focus of the research some themes have remained a constant feature, namely the ecotourism and environmental aspects, while new areas of focus such as climate change have emerged since 1997 when the first article on the subject was published.

Both in terms of depth (content analysis of papers) and breadth (assessment of four journals over a 25 year period) the findings of this study provide a comprehensive state of the art review of sustainable tourism research for use by researchers, students and practitioners alike. The paper has also added to the growing body of bibliometric studies in tourism (Hall, 2011; Lu \& Nepal 2009; Weiler et al., 
2012; Xiao \& Smith 2006a) and state of the art reviews of tourism research generally (Kim, 1998; Swain et al., 1998; Xiao \& Smith, 2006b).

One of the clear contributions of this study is that of "looking back in order to progress" (Butler, 1999). Having assessed where the field has traversed over the last two and a half decades attention can turn to considering what the emerging areas in sustainable tourism research will be over the next several decades. As noted, the focus on climate change will likely continue; one might ask whether climate change will become the new sustainable tourism with some already arguing that "addressing climate change is considered a prerequisite to sustainable development and therefore germane to advancing sustainable tourism research" (Scott, 2011, p.17).

There are other areas that may well emerge as foci for sustainable tourism research. Although acknowledged as an important aspect of sustainable tourism (Caton, 2012; Tribe, 2002), the influence of ethics has yet to fully emerge, and areas identified by Buckley (2012) such as prosperity, peace and so forth were not elicited through an objective measure of progress in the field. The degree to which such themes are likely to feature in sustainable tourism research in the future is, of course, a matter for another study. In addition, arising from the literature, there is a need to explore whether the recommendations, implications and future research highlighted by the sustainable tourism articles have been recursive. Such a study will provide key insights into the nature of academic sustainable tourism research and point towards the possible future progress of the field. Finally, there is considerable scope to explore the factors or agents within the publishing community that have influenced the proliferation of sustainable tourism research. 


\section{References}

Ballantyne, R., Packer, J., \& Axelsen, M. (2009). Trends in tourism research. Annals of Tourism Research, 36(1), 149-152.

Barrios, M., Borrego, A., Vilaginés, A., Ollé, C., \& Somoza, M. (2008). A bibliometric study of psychological research on tourism. Scientometrics, 77(3), 453-467.

Benckendorff, P., \& Zehrer, A. (2013). A network analysis of tourism research. Annals of Tourism Research, 43, 121-149.

Berke, P. R. (2002). Does sustainable development offer a new direction for planning? Challenges for the twenty-first century. Journal of Planning Literature, 17(1), 21-36.

Botterill, D., Haven, C., \& Gale, T. (2002). A survey of doctoral theses accepted by universities in the UK and Ireland for studies related to tourism, 1990-1999. Tourist Studies, 2(3), 283-311.

Bramwell, B. (2007). Opening up new spaces in the sustainable tourism debate. Tourism Recreation Research, 32(1), 1-9.

Bramwell, B., \& Lane, B. (1993). Sustainable tourism: An evolving global approach. Journal of Sustainable Tourism, 1(1), 1-5.

Bramwell, B., \& Lane, B. (2005). From niche to general relevance? Sustainable tourism, research and the role of tourism journals. Journal of Tourism Studies, 16(2), 52-62.

Bramwell, B., \& Lane, B. (2008). Priorities in Sustainable Tourism Research. Journal of Sustainable Tourism, 16(1), 1-4.

Bramwell, B., \& Lane, B. (2011). Critical research on the governance of tourism and sustainability. Journal of Sustainable Tourism, 19(4-5), 411-421.

Bramwell, B., \& Lane, B. (2012). Towards innovation in sustainable tourism research? Journal of Sustainable Tourism, 20(1), 1-7.

Bramwell, B., \& Lane, B. (2013). Getting from here to there: Systems change, behavioural change and sustainable tourism. Journal of Sustainable Tourism, 21(1), 1-4.

Buckley, R. (2012). Sustainable tourism: Research and reality. Annals of Tourism Research, 39(2), 528-546.

Buhalis, D., \& Law, R. (2008). Progress in information technology and tourism management: 20 years on and 10 years after the Internet - The state of eTourism research. Tourism Management, 29(4), 609-623.

Butler, R. (1999). Sustainable tourism: A state-of-the-art review. Tourism Geographies, 1(1), 7-25.

Butler, R., W. (1998). Sustainable tourism: Looking backwards in order to progress? In C. M. Hall \& A. A. Lew (Eds.), Sustainable Tourism: A Geographical Perspective (pp. 25-34). Harlow, UK: Longman.

Caton, K. (2012). Taking the moral turn in tourism studies. Annals of Tourism Research, 39(4), 19061928.

Collins, A. (1999). Tourism development and natural capital. Annals of Tourism Research, 26(1), 98109.

Darbellay, F., \& Stock, M. (2012). Tourism as complex interdisciplinary research object. Annals of Tourism Research, 39(1), 441-458.

Dowling, R. (1993). An environmentally-based planning model for regional tourism development. Journal of Sustainable Tourism, 1(1), 17-37.

Echtner, C. M., \& Jamal, T. B. (1997). The disciplinary dilemma of tourism studies. Annals of Tourism Research, 24(4), 868-883.

Frechtling, D. C. (2004). Assessment of tourism/hospitality journals' role in knowledge transfer: an exploratory study. Journal of Travel Research, 43(2), 100-107.

Gössling, S., \& Hall, C. M. (2006). Uncertainties in predicting tourist flows under scenarios of climate change. Climatic Change, 79(3-4), 163-173.

Gössling, S., \& Peeters, P. (2007). 'It does not harm the environment!'An analysis of industry discourses on tourism, air travel and the environment. Journal of Sustainable Tourism, 15(4), 402-417.

Gössling, S., Hall, C. M., \& Weaver, D. (2008). Sustainable Tourism Futures: Perspectives on Systems, Restructuring and Innovations: Routledge. 
Gössling, S., Hall, C. M., Ekström, F., Engeset, A. B., \& Aall, C. (2012). Transition management: a tool for implementing sustainable tourism scenarios? Journal of Sustainable Tourism, 20(6), 899-916.

Guilera, G., Barrios, M., \& Gómez-Benito, J. (2013). Meta-analysis in psychology: a bibliometric study. Scientometrics, 94(3), 943-954.

Hall, C. M. (1991). Tourism as the subject of post-graduate dissertations in Australia. Annals of Tourism Research, 18(3), 520-523.

Hall, C. M. (2011). Publish and perish? Bibliometric analysis, journal ranking and the assessment of research quality in tourism. Tourism Management, 32(1), 16-27.

Hardy, A., Beeton, R. J. S., \& Pearson, L. (2002). Sustainable tourism: An overview of the concept and its position in relation to conceptualisations of tourism. Journal of Sustainable Tourism, 10(6), 475-496.

Holden, A. (2009). The environment-tourism nexus: Influence of market ethics. Annals of Tourism Research, 36(3), 373-389.

Huang, S. S. (2011). Tourism as the subject of China's doctoral dissertations. Annals of Tourism Research, 38(1), 316-319.

Hunter, C. J. (1995). On the need to re-conceptualise sustainable tourism development. Journal of Sustainable Tourism, 3(3), 155-165.

Jafari, J., \& Aaser, D. (1988). Tourism as the subject of doctoral dissertations. Annals of Tourism Research, 15(3), 407-429.

Kim, S.-H. (1998). Content Analysis: Annals of Tourism Research \& Journal of Travel Research. (Master of Philosophy), University of Wisconsin-Stout.

Ko, J. T. (2001). Assessing progress of tourism sustainability. Annals of Tourism Research, 28(3), $817-820$.

Lane, B. (2009). Implementing sustainable tourism in Scotland: An interview. Journal of Sustainable Tourism, 17(6), 747-752.

Leiper, N. (1981). Towards a cohesive curriculum tourism: The case for a distinct discipline. Annals of Tourism Research, 8(1), 69-84.

Leiper, N. (2000). An emerging discipline. Annals of Tourism Research, 27(3), 805-809.

Loulanski, T., \& Loulanski, V. (2011). The sustainable integration of cultural heritage and tourism: a meta-study. Journal of Sustainable Tourism, 19(7), 837-862.

Lu, J., \& Nepal, S. K. (2009). Sustainable tourism research: an analysis of papers published in the Journal of Sustainable Tourism. Journal of Sustainable Tourism, 17(1), 5-16.

McKercher, B. (2005). A case for ranking tourism journals. Tourism Management, 26(5), 649-651.

McKercher, B., Law, R., \& Lam, T. (2006). Rating tourism and hospitality journals. Tourism Management, 27(6), 1235-1252.

McLennan, C. J., Moyle, B. D., \& Weiler, B. V. (2013). The Role of Economics in Tourism Postgraduate Research: An Analysis of Doctoral Dissertations Completed between 20002010. Journal of Applied Economics \& Business Research, 3(4), 181-191.

Meyer-Arendt, K. J., \& Justice, C. (2002). Tourism as the subject of North American doctoral dissertations, 1987-2000. Annals of Tourism Research, 29(4), 1171-1174.

Moyle, B. D., McLennan, C. J., Ruhanen, L., \& Weiler, B. (2014). Tracking the concept of sustainability in Australian tourism policy and planning documents. Journal of Sustainable Tourism, 22(7), 1037-1051.

Pao, M. L. (1985). Lotka's law: a testing procedure. Information Processing \& Management, 21(4), 305-320.

Pechlaner, H., Zehrer, A., Matzler, K., \& Abfalter, D. (2004). A ranking of international tourism and hospitality journals. Journal of Travel Research, 42(4), 328-332.

Ramos-Rodríguez, A. R., \& Ruíz-Navarro, J. (2004). Changes in the intellectual structure of strategic management research: A bibliometric study of the Strategic Management Journal, 1980 2000. Strategic Management Journal, 25(10), 981-1004.

Reid, L. J., \& Andereck, K. L. (1989). Statistical analyses use in tourism research. Journal of Travel Research, 28(2), 21-24.

Riley, R. W., \& Love, L. L. (2000). The state of qualitative tourism research. Annals of Tourism Research, 27(1), 164-187. 
Ruhanen, L. (2013). Local government: facilitator or inhibitor of sustainable tourism development? Journal of Sustainable Tourism, 21(1), 80-98.

Ryan, C. (2005). The ranking and rating of academics and journals in tourism research. Tourism Management, 26(5), 657-662.

Saarinen, J. (2006). Traditions of sustainability in tourism studies. Annals of Tourism Research, 33(4), 1121-1140.

Scott, D. (2011). Why sustainable tourism must address climate change. Journal of Sustainable Tourism, 19(1), 17-34.

Scott, D., \& Becken, S. (2010). Adapting to climate change and climate policy: progress, problems and potentials. Journal of Sustainable Tourism, 18(3), 283-295.

Sharpley, R. (2000). Tourism and sustainable development: Exploring the theoretical divide. Journal of Sustainable Tourism, 8(1), 1-19.

Sharpley, R. (2009). Tourism development and the environment: Beyond sustainability? London: Earthscan.

Sheldon, P. J. (1990). Journals in tourism and hospitality: the perceptions of publishing faculty. Journal of Tourism Studies, 1(1), 42-48.

Sheldon, P. J. (1991). An authorship analysis of tourism research. Annals of Tourism Research, 18(3), 473-484.

Shilbury, D. (2011). A bibliometric study of citations to sport management and marketing journals. Journal of Sport Management, 25(5), 423-444.

Singh, T. V., \& Singh, S. (1999). Tourism development in critical environments. New York: Cognizant Communication Corporation.

Song, H., Dwyer, L., Li, G., \& Cao, Z. (2012). Tourism economics research: A review and assessment. Annals of Tourism Research, 39(3), 1653-1682.

Swain, M. B., Brent, M., \& Long, V. H. (1998). Annals and tourism evolving: indexing 25 years of publication. Annals of Tourism Research, 25, 991-1014.

Thomson Reuters. (2013). Journal Citation Reports: Social Sciences Edition. Retrieved 5 March, 2014, from http://wokinfo.com/products_tools/analytical/jcr/

Torres-Delgado, A., \& Palomegue, F. L. (2012). The growth and spread of the concept of sustainable tourism: The contribution of institutional initiatives to tourism policy. Tourism Management Perspectives, 4, 1-10.

Tribe, J. (1997). The indiscipline of tourism. Annals of Tourism Research, 24(3), 638-657.

Tribe, J. (2000). Indisciplined and unsubstantiated. Annals of Tourism Research, 27(3), 809-813.

Tribe, J. (2002). Education for ethical tourism action. Journal of Sustainable Tourism, 10(4), 309-324.

Van Raan, A. F. (2004). Sleeping beauties in science. Scientometrics, 59(3), 467-472.

Van Raan, A. F. (2005). Fatal attraction: Conceptual and methodological problems in the ranking of universities by bibliometric methods. Scientometrics, 62(1), 133-143.

Weaver, D. (2011). Can sustainable tourism survive climate change? Journal of Sustainable Tourism, $19(1), 5-15$.

Weaver, D. B. (2012). Organic, incremental and induced paths to sustainable mass tourism convergence. Tourism Management, 33(5), 1030-1037.

Weaver, D. B. (2014). Asymmetrical dialectics of sustainable tourism toward enlightened mass tourism. Journal of Travel Research, 53(2), 131-140.

Weiler, B., Moyle, B., \& McLennan, C.-1. (2012). Disciplines that influence tourism doctoral research: the United States, Canada, Australia and New Zealand. Annals of Tourism Research, 39(3), 1425-1445.

Whitford, M. (2009). A framework for the development of event public policy: Facilitating regional development. Tourism Management, 30(5), 674-682.

World Commission on Environment and Development (WCED). (1987). Report of the World Commission on Environment and Development: Our Common Future Retrieved 6 March, 2013, from http://www.un-documents.net/our-common-future.pdf

Xiao, H., \& Smith, S. L. (2006a). The making of tourism research: Insights from a social sciences journal. Annals of Tourism Research, 33(2), 490-507.

Xiao, H., \& Smith, S. L. (2006b). The maturation of tourism research: Evidence from a content analysis. Tourism Analysis, 10(4), 335-348. 
1

2

3

4

5

6

7

8

9

10

11

12

13

14

15

16

17

18

19

20

21

22

23

24

25

26

27

28

29

30

31

32

33

34

35

36

37

38

39

40

41

42

43

44

45

46

47

48

49

50

51

52

53

54

55

56

57

58

59

60
Xiao, H., \& Smith, S. L. (2006c). Case studies in tourism research: A state-of-the-art analysis. Tourism Management, 27(5), 738-749.

Xiao, H., \& Smith, S. L. (2007). The use of tourism knowledge: Research propositions. Annals of Tourism Research, 34(2), 310-331.

Xiao, H., \& Smith, S. L. (2008). Knowledge impact an appraisal of tourism scholarship. Annals of Tourism Research, 35(1), 62-83. 


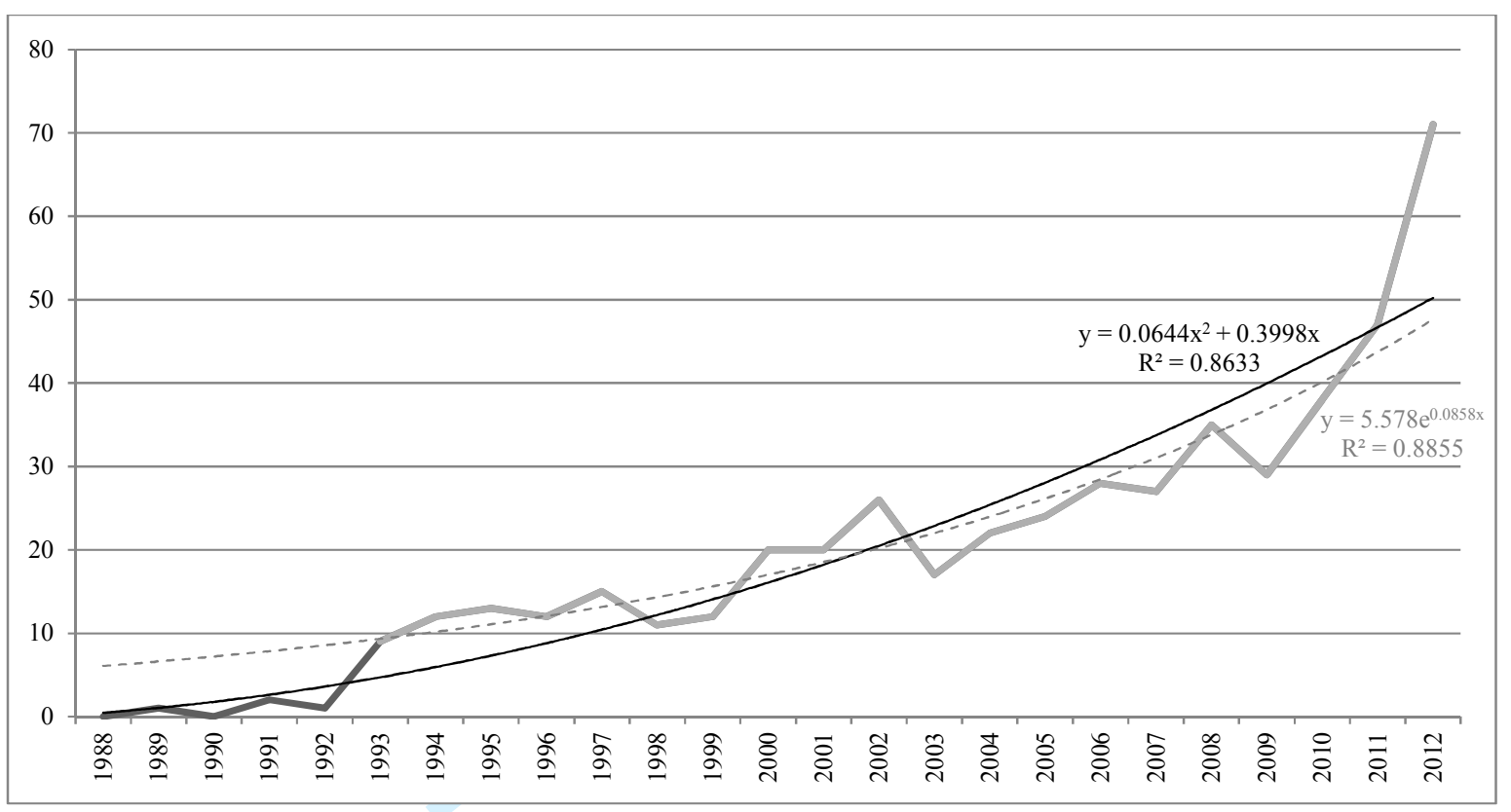

Figure 1. Growth in sustainable tourism research in the four leading tourism journals, 1987-2012 
Table 1. Theoretical and methodological approaches in sustainable tourism research

\begin{tabular}{|l|l|c|c|}
\hline \multicolumn{1}{|c|}{ Approach } & \multicolumn{1}{|c|}{ Coding Descriptor } & $\begin{array}{c}\text { Count } \\
(\boldsymbol{n})\end{array}$ & $\begin{array}{c}\text { \% } \\
\text { articles }\end{array}$ \\
\hline Case study & Descriptive or explanatory analysis of a single place/event/issue & 172 & $35 \%$ \\
\hline Empirical study & $\begin{array}{l}\text { Contributes to theory development through direct } \\
\text { observation/testing, analysed qualitatively or quantitatively }\end{array}$ & 83 & $17 \%$ \\
\hline Critical review & $\begin{array}{l}\text { Review/analysis of theory/concept, often using theory/literature } \\
\text { from other disciplines, to analyse a tourism related issue }\end{array}$ & 81 & $16 \%$ \\
\hline $\begin{array}{l}\text { Theory (model) } \\
\text { building }\end{array}$ & $\begin{array}{l}\text { Development or adaption of a model/typology to describe/ } \\
\text { understand tourism processes }\end{array}$ & 34 & $7 \%$ \\
\hline $\begin{array}{l}\text { Comparative case } \\
\text { study }\end{array}$ & Compares two or more cases & 29 & $6 \%$ \\
\hline Literature review & Critical reviews of the literature on a particular topic/s & 26 & $5 \%$ \\
\hline $\begin{array}{l}\text { Theory } \\
\text { framework) } \\
\text { building }\end{array}$ & $\begin{array}{l}\text { Development or adaption of a framework that can be used to } \\
\text { address an issue (or range of issues) in tourism }\end{array}$ & $4 \%$ \\
\hline $\begin{array}{l}\text { Theory } \\
\text { (methodology) } \\
\text { development }\end{array}$ & $\begin{array}{l}\text { Development of methodological techniques/tools to enhance the } \\
\text { analysis of a certain issue in tourism research }\end{array}$ & 13 & $3 \%$ \\
\hline $\begin{array}{l}\text { Theory (concept) } \\
\text { development }\end{array}$ & $\begin{array}{l}\text { Re-conceptualisation of a tourism concept through application of } \\
\text { theory from other disciplines to tourism }\end{array}$ & 11 & $2 \%$ \\
\hline $\begin{array}{l}\text { Historical } \\
\text { perspective }\end{array}$ & $\begin{array}{l}\text { Analyses of past events/occurrences to make recommendations } \\
\text { for the future }\end{array}$ & 11 & $2 \%$ \\
\hline
\end{tabular}


Table 2. Subjects and contextual themes in sustainable tourism research

\begin{tabular}{|l|l|c|c|}
\hline \multicolumn{1}{|c|}{ Subject/theme } & \multicolumn{1}{|c|}{ Coding Descriptor } & $\begin{array}{c}\text { Count } \\
\text { N }\end{array}$ & $\begin{array}{c}\text { \% } \\
\text { articles }\end{array}$ \\
\hline $\begin{array}{l}\text { Sustainable } \\
\text { tourism practice }\end{array}$ & General processes, practices, theories, trends & 95 & $19 \%$ \\
\hline $\begin{array}{l}\text { Sustainable } \\
\text { tourism } \\
\text { development }\end{array}$ & General development theory or practice & 50 & $10 \%$ \\
\hline $\begin{array}{l}\text { Nature-based } \\
\text { tourism }\end{array}$ & Experiences in natural settings i.e. diving, wildlife tourism & 36 & $7 \%$ \\
\hline Protected areas & World Heritage sites, national parks, marine parks and reserves & 35 & $7 \%$ \\
\hline $\begin{array}{l}\text { Island } \\
\text { destinations }\end{array}$ & Small Island Developing States, offshore islands & 32 & $7 \%$ \\
\hline Ecotourism & Ecotourists, ecotourism businesses, general theory and practices & 28 & $6 \%$ \\
\hline $\begin{array}{l}\text { Developing } \\
\text { countries }\end{array}$ & Developing or least developed country contexts & 27 & $5 \%$ \\
\hline Rural tourism & Rural, farm, woodland tourism & 22 & $4 \%$ \\
\hline Accommodation & Hotels, resorts, other accommodation & 20 & $4 \%$ \\
\hline Sports/recreation & Leisure, recreation, sport tourism, adventure tourism & 18 & $4 \%$ \\
\hline Climate change & Climate change as a study context & 18 & $4 \%$ \\
\hline Heritage & Archaeological sites, heritage sites excl. world heritage & 16 & $3 \%$ \\
\hline Cultural tourism & Cultural experiences and behaviour, Aboriginal, ethnic peoples & 16 & 16 \\
\hline Tourists & Tourist activity, behaviours, motivations & 15 & $3 \%$ \\
\hline Events & Events, festivals, conferences, meetings & 15 \\
\hline Transport/travel & Transportation modes, travel patterns & $3 \%$ \\
\hline
\end{tabular}


Table 3. Perspectives/approaches to sustainable tourism research

\begin{tabular}{|l|l|c|c|}
\hline Perspective/approach & \multicolumn{1}{|c|}{ Coding Descriptor } & $\begin{array}{c}\text { Count } \\
n\end{array}$ & $\begin{array}{c}\% \\
\text { articles }\end{array}$ \\
\hline Planning & Management, strategy, implementation and assessments & 95 & $19 \%$ \\
\hline Behavioural & Tourist/resident/business behaviour, change, motivations & 60 & $12 \%$ \\
\hline Perception & $\begin{array}{l}\text { Tourist, resident, community and business perception and } \\
\text { attitude studies }\end{array}$ & 52 & $11 \%$ \\
\hline $\begin{array}{l}\text { Tourism research } \\
\text { theory/methods }\end{array}$ & $\begin{array}{l}\text { Methodological approaches including ontology, } \\
\text { paradigms, definitions, approaches to research on } \\
\text { sustainable tourism }\end{array}$ & 50 & $10 \%$ \\
\hline $\begin{array}{l}\text { Indicators and } \\
\text { measurement }\end{array}$ & $\begin{array}{l}\text { Tools and approaches to sustainability assessments, } \\
\text { indicators, limits to growth, GIS }\end{array}$ & 44 & $9 \%$ \\
\hline Policy & Policy, governance and politics & 44 & $9 \%$ \\
\hline Stakeholders & $\begin{array}{l}\text { Collaboration, stakeholder and network theories, } \\
\text { partnerships, communities participation }\end{array}$ & 42 & $9 \%$ \\
\hline Impact studies & $\begin{array}{l}\text { Environmental, economic, social, cultural impacts of } \\
\text { tourism }\end{array}$ & 31 & $6 \%$ \\
\hline Visitor management & Interpretation, tourist/visitor education & 19 & $4 \%$ \\
\hline Marketing & General marketing studies, market segmentation & 18 & $4 \%$ \\
\hline $\begin{array}{l}\text { Climate change } \\
\text { studies }\end{array}$ & $\begin{array}{l}\text { Measurement, management, adaptation/mitigation, } \\
\text { impacts }\end{array}$ & 23 & $4 \%$ \\
\hline Economics & Tourist spending, taxation & 11 & $2 \%$ \\
\hline
\end{tabular}

